\title{
Indigenous Publicity in American Public Lands Controversies: Environmental Participation in the Fight for Bears Ears National Monument
}

\section{OPEN ACCESS}

Edited by:

Carlos Anthony Tarin, The University of Texas at El Paso, United States

Reviewed by: Jennifer Peeples, Utah State University, United States Emma Frances Bloomfield, University of Nevada, Las Vegas, United States

*Correspondence:

Taylor N. Johnson tjohnson3@uwlax.edu

Specialty section: This article was submitted to Science and Environmental Communication,

a section of the journal Frontiers in Communication

Received: 26 February 2021 Accepted: 15 July 2021 Published: 28 July 2021

Citation: Johnson TN (2021) Indigenous Publicity in American Public Lands

Controversies: Environmental Participation in the Fight for Bears Ears National Monument.

Front. Commun. 6:673115. doi: $10.3389 /$ fcomm.2021.673115
Taylor N. Johnson*

Department of Race, Gender, and Sexuality Studies, University of Wisconsin - La Crosse, La Crosse, WI, United States

Environmental decision-making scholars have attended closely to the role of publics and counterpublics in environmental controversies. However, this body of work has undertheorized the ways that Indigeneity may complicate access to or desirability of American publicity as a driving force in environmental advocacy. Inclusion within the American national body both functions as an advocacy tool for Native people and as a colonial discourse that may undermine sovereignty goals. Through a critical rhetorical analysis of documents at the center of the controversy over Bears Ears National Monument, this essay explicates the deployment of American publicity both to support and to undermine Native advocacy for the Monument. Scholars of rhetoric and environmental decision-making must re-orient toward publicity in a way that accounts for settler colonialism and decolonization.

Keywords: publics and counterpublics, rhetoric, environmental decision making, Native American and Indigenous Studies, public land, bears ears national monument

\section{INTRODUCTION}

In 2015, a group of five Native ${ }^{1}$ governments (the Navajo Nation, the Hopi Tribe, the Ute Indian Tribe, the Ute Mountain Ute Tribe, and the Zuni Tribe) published a proposal for the creation of Bears Ears National Monument. The proposal defined a territory of 1.9 million acres and argued that this portion of Southern Utah holds historical, natural, and cultural value to both Native people and non-Native Americans. In 2016, then-U.S. President Barack Obama responded to the Bears Ears Intertribal Coalition's (BEITC) proposal, designating 1.35 million acres as a national monument. While the response offered hope that the lands would be protected, it also brought complications. Although the BEITC had called for Tribes to manage the monument in partnership with the United States federal government, Obama's proclamation granted only an advisory role to the Tribes

${ }^{1}$ Throughout this essay, I use the terms Native, Native American, and Indigenous largely interchangeably. As Bruyneel notes, the choice of terms is fraught with tension. When choosing terms, I generally echo the language used by the authors and organizations I cite. Similarly, I use the terms Tribe and Tribal to echo the language of the BEITC and also to recognize that some members of the BEITC (i.e., the Ute Indian Tribe and the Ute Mountain Ute Tribe) share a broader community that has been fractured as a result of colonialism. I recognize that this terminology is contested, and in places where I am not referring to the five member Tribes of the BEITC or specific legal bodies that use the term Tribe, I use the term nation (Bruyneel, 2007). 
(Bears Ears Inter-Tribal Coalition, 2015; U.S. President, 2016). Additionally, the proposal's explicit focus on ongoing cultural practices important to Native communities with ties to the region was stripped from the proclamation, minimizing the focus on Indigenous rights that had animated the proposal.

The tension over Native rights at Bears Ears escalated with the 2016 election of Donald Trump to the office of the President of the United States. In December 2017, Trump released a proclamation reducing the size of the monument to roughly 200,000 acres roughly an $85 \%$ reduction in size from the Obama designation (U.S. President, 2017). Echohawk (2017) (Pawnee), director of the Native American Rights Fund, denounced Trump's proclamation as "an illegal attack on tribal sovereignty." Echohawk argued that the Trump administration had failed to meet its obligation to consult with Native nations as part of the decision-making process required by law or to engage in government-to-government relations with Tribes invested in the Monument. The Trump administration touted the reduction in size as a victory for public interests, with Secretary of the Interior Ryan Zinke stating that "public lands are for public use and not for special interests" (Davidson and Burr, 2017). This statement drew criticism from both Native people and non-Native environmentalists, who challenged Zinke's framing of people "that have lived and used these lands since time immemorial" and protection of sacred landscapes as a special interest (Branch and Cordalis, 2018). The framing of Indigenous sovereignty as a special interest, they argued, was couched in logics that center nonNative desires over the needs of Native people.

Zinke's statement was indicative of the Trump administration's general disregard for Native peoples in regards to the Bears Ears designation and demonstrated an unwillingness to de-center settler concerns and unfettered extractive industry growth in land use decisions. ${ }^{2}$ Indeed, by framing the concerns of Native people as separate from "public use," Zinke emphasized a monolithic understanding of the American public that marginalizes or ignores Native people while simultaneously uplifting the interests of extractive industries as a desirable core of public use (Lipton and Friedman, 2018).

While the Trump administration's approach toward public lands designations and Native peoples was particularly callous, the problem extends beyond Trump's designations to implicate the entire system of environmental decision-making in the United States. The fight to protect Bears Ears points toward fundamental challenges to the logics that govern environmental decision-making and public lands usage in the United States. As Keeler (2017) (Diné (Navajo)/Dakota) argues, Bears Ears represents a struggle over the foundational values that steer decisions. Who and what is valued - and therefore which voices are heard, understood, and heeded - is a question of vital importance for anyone invested in

\footnotetext{
${ }^{2}$ Throughout this essay, I align my definition of the term "settler" with the thinking of scholars like Tuck and Yang (2012), 5, who write that "settlers come with the intention of making a new home on the land, a homemaking that insists on settler sovereignty over all things in their new domain." In other words, settlers are nonNative people whose occupation of colonized lands is tied up with the elimination of Native peoples and societies (Wolfe, 2006).
}

struggle over land, environmental policy, and Indigenous rights. As Smith (2020) has noted, the shifting boundaries of Bears Ears reflect fluid but always-present neoliberal priorities of the US government during the Obama and Trump eras, particularly commitments to extractive industries.

Through a rhetorical analysis of the BEITC's proposal and the presidential proclamations establishing and shrinking the monument, this essay argues that Native people are often positioned as simultaneously within and outside of the American public sphere by government officials, agencies, and policies central to environmental decision-making processes. As such, Native voices are often silenced in the context of public participation in environmental decision-making. The BEITC's proposal for Bears Ears National Monument highlights the ways that Native people navigate this territory by strategically deploying publicity - which I define as a group's position in relation to dominant publics and marginalized counterpublics or maneuvering around these designations - to gain access to deliberative processes. This pursuit of access, however, is distinct from inclusion in the American body politic - which is tied up with "settler futurities" (Tuck and GaztambideFernández, 2013). This project draws from definitions of settler colonialism as an ongoing process or structure of invasion in which non-Native settlers arrive with the goal of replacing Native peoples (Wolfe, 2006). In this definition, elimination of Native peoples - through genocide, erasure, and assimilation - is a necessity of settler colonialism, because for settler colonialism's project to become complete, settlers must replace Native people and assume their own claims to belonging in the territories that they have colonized. Thus, settler futurities are necessarily premised on the foreclosure of Native futurities. The BEITC's approach, then, resists colonization by centering Indigenous sovereignty/separateness from the colonial state and offering models for decision-making processes where all of the sovereign nations with ties to Bears Ears are participants.

This maneuvering points toward a need for rhetorical scholars to re-orient toward the public sphere in a way that accounts for decolonization. Rather than pursuing a more inclusive standard of publicity (i.e., who counts as public and/or counterpublic), scholars must ask whether inclusion within the public sphere as it stands is even desirable in the first place. As I argue later in this essay, public sphere scholarship's focus on the ways that marginalized counterpublics participate in the production of political discourse, while valuable, has not sufficiently questioned the incommensurability of decolonization and inclusion within a settler public. Tuck and Yang $(2012,13)$ conceptualize decolonization as "Native futures without a settler state." In other words, decolonization requires the dismantling of settler institutions and the de-centering of settler interests in favor of restoring land and decision-making authority to Native nations. Thus, the pursuit of decolonization and the pursuit of inclusion within a public sphere that centers the improvement and continuance of a settler state run counter to one another. Thus, decolonization necessitates centering the agency of Indigenous nations not as a subset of the United States, but rather as sovereign entities. As environmental activist and executive director of Honor the 
Earth Winona LaDuke (2008) (Ojibwe) has stated, “we don't want a bigger piece of the pie. We want a different pie."

\section{PUBLIC LANDS, SETTLER COLONIALISM, AND "THE AMERICAN PUBLIC"}

I am a non-Native woman living and working at the time of writing in Salt Lake City, Utah in Ute, Paiute, Goshute, and Eastern Shoshone territory. My relationship to the state of Utah and my identity as a white woman have both been shaped by discourses surrounding public lands - particularly national parks and monuments. As a child growing up in the Missouri Ozarks on Oceti Sakowin, Osage, and Kickapoo land, I spent many weekends exploring national parks and forests, listening to interpreters in visitors' centers, and reading countless plaques and pamphlets provided by the National Park Service. For my working-class family, short road trips to nearby public lands provided the opportunity for vacation, education, and identity-formation as Americans all in one. The messages provided by the interpreters and reading materials often spoke of the pioneering American spirit, told celebratory stories of the white settlers who "civilized" or "discovered" these lands, and described the spaces as American treasures. Rarely, if ever, did they acknowledge or unpack the violent histories of colonization that underpinned the stories they told or incorporate Indigenous voices into their narratives.

Later, as a visitor to and prospective resident of Utah, I was showered with images of public lands. Tourists and residents alike are drawn to Utah by the natural wonders and outdoor activities the state offers. The outdoor recreation industry contributes more than $\$ 12.3$ billion annually to the Utah economy and is intimately linked to the way residents describe the state (Office of Outdoor Recreation). As Raka Shome has argued, it is essential that Western and settler scholars engage in self-reflexivity aimed at critically interrogating how our own embeddedness in colonial systems informs our research (Shome, 1996). My experiences with accessing and engaging with public lands lead me to an interest in how public lands in the United States are implicated in settler colonialism. I am invested in deconstructing the narratives that have defined my relationships to public lands and in unpacking how these narratives produce a monolithic understanding of the American public that results in unjust decision-making processes that undermine Native selfdetermination and agency in colonized spaces. ${ }^{3}$

\footnotetext{
${ }^{3}$ Throughout this essay I oscillate between the use of the terms "public" and "publics" to describe the multiplicity of people and discourses that make up the American public sphere. While I recognize the multiplicity of overlapping and networked publics and counterpublics that cannot be condensed into a singular American public, the documents produced by the US federal government that govern public lands and public participation in environmental decision-making repeatedly use terms such as "the public," "public good," "public interests," etc. These terms, along with implications within the documents that public lands benefit all members of the public equally, suggest that decision-making processes are de3signed via the rhetorical production of a singular and monolithic American public. For examples, see: (National Environmental Policy Act, 1969; National Historic Preservation Act, 1966; U.S. President, 2016; U.S. President, 2017).
}

Bears Ears presents an opportunity to consider the complicated relationships that Native Americans have to the American public, and to question how Native people strategically navigate decision-making processes in ways that affirm sovereignty and challenge colonialism. While both presidential proclamations discussed in this essay frame their decisions regarding the monument in terms of public goods, their interpretations of public goods differ radically. While the Obama proclamation devotes significant attention to the historical and cultural significance of Bears Ears for Native peoples, the text still places public good for a non-Indigenous American public at the center of the reasoning. The Trump proclamation, on the other hand, makes no mention of the significance of the site for Indigenous people, instead focusing on the scientific and natural resources at Bears Ears. In both cases, settler colonialism underpins the logics at play, serving to elevate the desires of settlers over Native people. Debates about Bears Ears, then, highlight to the colonial nature of American publicity.

As Wolfe, (2006) argues, settler colonialism is premised on the elimination of Native peoples and nations in order to make way for replacement by settler institutions. This process is both material and discursive - it involves both the literal theft, occupation, genocide, and destruction of Indigenous territories and rhetorics that devalue Indigenous people and normalize settler occupation and replacement. ${ }^{4}$ Thus, Native people's continued presence, their refusal to engage in the structures of settler colonial society (for example, through refusing citizenship from settler governments), and their continued participation in traditional practices all function as forms of resistance to settler colonialism and highlight the failure of the settler colonial project to reach completion (Bruyneel, 2007; Vizenor, 2008; Simpson, 2014; Barker, 2017).

Indigeneity, in this framework, is best understood as an analytic. As Na'puti (2019, 497) (Chamoru) notes, Indigeneity as analytic centers questions of ancestry/kinship as distinct from "the logics of blood quantum, race, ethnicity, or nationality." Approaching Indigeneity as an analytic allows scholars to recognize the ways that processes of racialization and colonialism are intertwined and appreciate the importance of Indigeneity as identity, while also acknowledging the unique territorial claims of Indigenous people that are obfuscated by centering frames like race or nationality. Indeed, several scholars have highlighted the importance of not conflating race or nationality with Indigeneity, but instead understanding race and settler colonialism as mutually supportive and overlapping systems (Wolfe, 2001; Stephenson, 2002; Morgensen, 2011). Although Indigenous communities in the United States certainly face racialized violence, they also face unique violences related to dispossession and erasure of their continued existence and territorial claims that cannot be boiled down simply to race.

\footnotetext{
${ }^{4}$ Even metaphors like the title of this journal - Frontiers - may reproduce settler logics. There has been substantial scholarship on the rhetorical facets of colonialism. For example: (Sanchez et al., 1999; Wolfe, 2001; Wolfe, 2006; Endres, 2009)
} 
In the context of environmental policy, approaching Indigeneity as analytic requires thinking through not only the national affiliations of Indigenous people, but also through the ways that publics are rhetorically constructed by the colonial state to privilege settlers' territorial claims over those of Native people. I turn toward theories of the public sphere, then, to understand the rhetorical production of belonging and inclusion that governs access to participatory processes that define communities via more expansive criteria than citizenship. While citizens are often centered in public participatory processes, the regulatory frameworks that govern these processes do not define "the public" merely as a function of citizenship (in fact, these regulatory frameworks provide very little, if any, definition of "the public" at all) (National Environmental Policy Act, 1969). Access to participation, then, is not necessarily premised solely on legal inclusion in the colonial state, but rather on membership in broader discourse communities with assumed shared values and goals. This essay explores the tensions of deliberative processes that are revealed by the question; who is the public in "public land," "Public participation," and "public good"? The BEITC's work suggests that these terms cannot be taken for granted in a settler colonial context.

Thus, the remainder of this essay is organized in three sections. First, I develop a framework for understanding the relationship between Native sovereignty and the public sphere. Second, I analyze the BEITC's proposal, the Obama proclamation, and the Trump proclamation to tease out the varied and juxtaposed portrayals of Native people's relationships to the United States with a particular focus on how publics and counterpublics are constructed in these documents. I highlight the varied ways that Indigenous people are positioned in relation to the American public in these documents in order to suggest that federal government processes for designating and managing public lands are ill-suited for recognizing Native people's territorial claims or facilitating Native governance over public lands. Finally, I argue that the BEITC's proposal navigates the constraints of settler colonial decision-making processes by strategically deploying the often-contradictory rhetorics through which settlers position Native people in relation to the American public as a tool for framing Bears Ears National Monument as a public good. Although this rhetorical maneuvering is a useful approach for Native people working to protect land in the context of decision-making processes controlled by the colonial government, it also exposes the tensions of representative democracy, citizenship, and publicity in the context of environmental decision-making and points toward a need to reject settler-defined notions of "the public" as an organizing force for access to participatory processes. Native relationships to territory are rendered illegible in extant settler logics of public participation in public lands designation and management, as can be particularly seen in the Presidential responses to the monument plan.

\section{PUBLIC PARTICIPATION, CITIZENSHIP, NATIONHOOD, AND THE PUBLIC SPHERE}

The official federal processes for public participation central to environmental decision-making are built on the foundational assumption that there is a singular and achievable "public good" that benefits a monolithic "American public." This assumption is reflected in secretary Zinke's statement that "public lands are for public use and not for special interests," and codified in the National Environmental Policy Act (NEPA) and the National Historic Preservation Act (NHPA) (National Historic Preservation Act, 1966; National Environmental Policy Act, 1969; Davidson and Burr, 2017). For example, NEPA, which is the regulatory foundation of much of the participatory process in environmental decision-making, frames public participation as a tool to "assure for all Americans safe, healthful, productive, and aesthetically and culturally pleasing surroundings" (National Environmental Policy Act, 1969). Similarly, the NHPA, which mandates the preservation of lands and structures considered historically or culturally valuable, asserts the importance of historical preservation by stating, "the historical and cultural foundations of the Nation should be preserved as a living part of our community life and development in order to give a sense of orientation to the American people," and, "the preservation of this irreplaceable heritage is in the public interest so that its vital legacy of cultural, educational, aesthetic, inspirational, economic, and energy benefits will be maintained and enriched for future generations of Americans" (National Historic Preservation Act, 1966). Federal rhetoric thus constructs "the American public" as central to environmental and historical preservation, while simultaneously constructing a singular and monolithic "public interest" that assumes a universalist understanding of the public.

The metrics that determine inclusion in this monolithic public are not explicitly laid out in these documents, but rather function enthymematically to point vaguely toward members of communities with ties to American identity who are affected by issues of environmental and historical preservation. These vague yet universalist references toward "the public," are crucial for understanding who has meaningful access to decision-making spaces. While much of the extant literature on public participation in environmental decision-making utilizes the vocabulary of citizenship to discuss participant communities, the regulatory frameworks that govern the processes do not include explicit references to citizenship as a determinant of membership in "the public" (for example: Kinsella, 2004; Council on Environmental Quality, 2007; Phillips et al., 2012; Sprain and Reinig, 2018). Access to participation, then, is not necessarily premised on legal inclusion in the colonial state via citizenship but rather on stakeholder status. Nevertheless, the question of citizenship has been crucial in shaping the relationships of Native nations to the US federal government and cannot be ignored when considering Native participation in federal decision-making processes. Thus, I turn both toward theories of citizenship/sovereignty and theories of publics/ counterpublics to tease out the relationship between publicity and access to deliberative processes.

Numerous scholars, both within the field of rhetoric and in other fields, have studied the role of citizenship in shaping relationships between Native people and the US government. These scholars highlight the ways that citizenship rhetorics alternately include or exclude Native Americans in federal conceptions of the "American public," serving the needs of the 
US government to both constrain Indigenous people's selfgovernance and deny access to funding and resources from the federal government (Wolfley, 1991; Witkin, 1995; Deloria, 1988; Black, 2008; Simpson, 2014). These scholars have highlighted the ways that the US government has alternately imposed or denied citizenship to Native peoples to further the colonial project. Others have noted the importance of treaties for shaping relationships between the US and Indigenous nations, arguing that treaties and treaty violation have similarly functioned to construct Native people as alternately within or outside of the U.S. body politic depending on the strategic goals of the U.S. government at any given time (Deloria and Wilkins, 1999). At the same time, scholars note that Native people have navigated these constraints, strategically engaging with colonial rhetorics of citizenship and inclusion in order to access decisionmaking power, practice inherent sovereignty, and/or demand benefits from the government that enable continued Native survival in the face of colonial constraints (Black, 2008; Endres, 2009; Simpson, 2014).

Theories of the public sphere provide powerful analytic tools for understanding the communicative processes through which private individuals come together to produce discourse that coalesces to inform the political sphere. Originating with Habermas (1989), public sphere scholarship works to theorize the ways private individuals engage one another in rational discourse as a way of bearing on decisions made by the state (Habermas, 1989). Members of the public, Habermas argues, must participate in public discourse in order to prevent state tyranny. A number of scholars, however, have argued that Habermas's conception of the public sphere excludes marginalized voices (Fraser, 1990; Benhabib, 1996; Young, 1996; Asen, 2000). These scholars argue that Habermas's conception of the public sphere assumes that all participants have equal footing in the discussion and brackets power imbalances. They criticize this assumption that having access to the public sphere is sufficient to overcome the factors that exclude marginalized groups from decision-making spaces. For example, Fraser (1990) argues that the form of the public sphere fails to account for the inequitable distribution of vocal space between groups. While previous scholars conceptualize the public sphere as a neutral space, Fraser challenges this understanding. She draws from Spivak's (1988) work on the subaltern in order to argue that marginalized individuals may continue to be underrepresented in the public sphere because white men are more likely to speak more frequently. She suggests that marginalized groups form "subaltern counterpublics" through which they can make their voices heard in the face of discursive exclusion.

Fraser's work has animated a thriving body of literature that discusses counterpublic resistance to dominant discourses. Robert Asen (2000), for example, suggests that counterpublics are emergent collectives that center around exclusions in dominant discourses. Counterpublics, he argues, cannot be reduced merely to a group of people who share an identity category, live in a particular locale, or have interests in a specific topic, but rather represent discourse communities. Furthermore, numerous scholars have noted that the public sphere is characterized by multiplicity, agonistic engagement, and interconnected networks of relationships (Fraser, 1990; Benhabib, 1996; Asen, 2000). These scholars argue both that a singular monolithic public is impossible to achieve and that the presence of a plurality of interconnected publics signifies a move toward representative democracy in which a multiplicity of voices are represented (Fraser, 1990; Benhabib, 1996; Hauser and Benson, 1999; Asen, 2000).

In this framework, counterpublics are made up of individuals who coalesce around a discursive exclusion and work together to challenge that exclusion from the public sphere. Thus, discursive engagement is the primary defining factor for a counterpublic. This is not to suggest, however, that the public sphere is made up of a binary of a singular dominant public and marginalized counterpublics. Indeed, a number of scholars have highlighted the overlapping nature of publics and counterpublics, and have argued that we should instead understand the public sphere as being made up of a network of relationships connected via discourse (Asen, 2000; Pezzullo, 2003). Additionally, scholars have highlighted the ways that these networks have become increasingly interconnected in the digital era (Friedland et al., 2006; Pfister, 2014). Pezzullo (2003) complicates this conversation, arguing that scholars have assumed a false dichotomy between publics and counterpublics. She proposes that some rhetorics may be both part of a dominant public discourse, and part of a counterpublic discourse. For example, she studies resistance to National Breast Cancer Awareness Month (NBCAM) and argues that the campaign functioned as a counterpublic discourse that forwarded women's health and worked to raise awareness about an important disease, while simultaneously reinforcing dominant discourses that obscured the role the companies sponsoring NBCAM played in producing harmful chemicals that contributed to breast cancer. This complicity was challenged by a second counterpublic that sought to highlight the neoliberal element of NBCAM.

This essay builds on Pezzullo's work by considering the ways Indigenous people have been positioned in relation to the American public. Bears Ears offers an opportunity to understand the strategic implications of being positioned as part of a public or counterpublic in particular circumstances. For Indigenous people who have often been alternatively included in or excluded from the American public at the whim of the U.S. government, strategically framing themselves as part of the American public or as outside of that public may serve as a site of resistance to colonial control, or as a way to gain access to decision-making spaces. Furthermore, this case study illuminates the ways in which decolonization calls not for an expansion of the American public to be more inclusive of Native people, but rather a dismantling of the very frameworks of publicity that naturalize settler dominance in decision-making processes.

The relationship between settler colonialism and the public sphere raises distinct issues of exclusion, inclusion, and the potential for collaboration. The incommensurability of decolonization with settler futurities poses a challenge for theories of counterpublic activism that center inclusion as the corrective to marginalization (Tuck and Yang, 2012). Much public sphere scholarship still centers inclusion as the primary 
goal of counterpublics, even as it recognizes that counterpublics may sometimes articulate themselves as explicitly separate from wider publics. Asen $(2000,441)$, for example, locates the "counter" of counterpublics in the identification of exclusion and the "resolve ... to overcome exclusion." Similarly, Stephenson (2002) theorizes Indigenous counterpublics as discourse communities characterized both by opposition to systematic domination and by the centrality of land claims and struggle for self-determination. She argues that "Indigenous movements for self-determination and autonomy are directly contesting the policies and practices of neoliberal reform and resisting a 'single relationship between the state and its citizens," but she does not challenge the notion that inclusion in the national body politic (either through citizenship or some other metric) is central to publicity itself as extant literature conceptualizes it.

My argument more closely aligns with work on consummatory rhetoric and inherent sovereignty, which asserts that Indigenous rhetorics need not always pursue inclusion or the granting of rights from colonial institutions, but instead may often function to enact or affirm the inherent rights of Indigenous peoples. For example, Lake's (1983) important work on the American Indian Movement argues that the movement's use of prayer and ceremony served a consummatory function of Indigenous world-making through traditional practices. Similarly, many scholars have theorized inherent sovereignty, arguing that sovereignty is not merely a legal status granted or recognized by the colonial state, but rather a practice or right inherently held by Indigenous nations (Fairbanks, 1995; Hannum, 1998; Coffey and Tsosie, 2001; Cobb, 2005; EagleWoman, 2012). From this perspective, a focus on sovereignty does not center recognition from the colonial state, but instead emphasizes Native practices of selfdetermination in defiance of colonial oppression. As I argue later in this essay, the BEITC's proposal makes visible these functions of Indigenous rhetoric by refusing to pursue mere inclusion within dominant conceptions of the American public. Instead, the BEITC deploys the histories of inclusion and exclusion experienced by members of the five Tribes in order to challenge the very framework of publicity that governs environmental decision-making practices in the United States and demand a participatory process grounded in Indigenous practices of sovereignty and shared decision-making authority.

Access to deliberative spaces and decision-making authority has historically been predicated on inclusion within a public sphere invested in the re-production of settler futurities. Exclusion has thus been used as a way to deny access to decision-making spaces and inclusion has been the most viable in-road for achieving access. This, however, undermines Native nations' sovereignty, predicating Native participation in decisionmaking processes on acceptance of these settler foundations for publicity. It may be more useful to understand environmental decision-making processes as spaces where individuals and nations engage in a relational practice of sovereignty in which decision-making authority is shared between distinct nations without the assumption of shared belonging in an American public or commitments to "public good." From this perspective, the question of inclusion or exclusion becomes secondary to the question of access. Rather than seeking inclusion within the settler state or the American public, the BEITC seeks access to decision-making spaces that have for too long been open only to those invested in settler futurities. Thus, I argue that the BEITC's proposal offers a model for collaboration between Native nations and the US government in which access to and participation in decision-making spaces is severed from assumptions about inclusion within an American public that centers settler futurities.

The BEITC's proposal centers a Collaborative Management Plan that diverges significantly from extant processes for consultation or collaboration between the US and Native governments, which have typically been primarily bilateral affairs. The problem of developing meaningful collaboration and consultation processes has been particularly troublesome in the context of environmental decision-making, not only in regards to federal consultation with Tribal governments, but also in terms of agencies engaging in public participatory processes more broadly (Cox, 1999; Senecah, 2004; Walker et al., 2015; Youdelis, 2016). Numerous scholars have highlighted agency practices that minimize public engagement in favor of brief and unilateral processes. For example, Hendry (2004) identifies a process she calls "Decide, Announce, Defend" in which federal agencies treat public input periods not as opportunities to listen and adapt to public concerns, but rather as platforms to advocate for decisions that have already been made to the public. Additionally, this lack of concern for public input is often exacerbated when the communities primarily affected by a decision are low-income communities and/or communities of color (Cox, 1999; Senecah, 2004; Bell, 2013; Evans, 2020). For Native communities, these issues intersect with settler colonial erasure of Indigenous knowledge and resistance to sovereignty to create even greater injustices (Ishiyama, 2003; Endres, 2009; Endres, 2012; Endres, 2013; Hoover, 2017; Estes, 2019; Johnson, 2019). Thus, the stakes of decision-making process design are particularly high for Native communities, for whom decisions affect not only community health and resources, but also the ability to practice selfgovernance without interference. As Bonney Hartley (Stockbridge-Munsee Mohican) writes, "the tensions [in consultation processes] are rooted in the inherent contradiction between two sovereignties, one based on preservation of indigenous culture and history, the other aimed at settler pride and state-building. The success of the latter seems to necessitate the containment or even erasure of the former" (Witt and Hartley, 2020). When combined with the construction of a monolithic public through policies like NEPA and the NHPA discussed earlier in this essay, public participation processes may undermine Native nations by treating their concerns as either less important than those of "the American public," or as merely a minor subset of broader public input, rather than as the legitimate input of sovereign nations.

The BEITC's proposal, by contrast, calls for the creation of a commission that includes representatives from each of the five Tribes alongside representatives from the three federal agencies responsible for managing national monuments (the Parks Service, the Forest Service, and the Bureau of Land 
Management) (Bears Ears Inter-Tribal Coalition, 2015). This commission would have decision-making authority over the monument, thus centering Native voices without flattening Native experience by privileging one Tribe over another (Bears Ears Inter-Tribal Coalition, 2015). This model is rooted in Indigenous perspectives and committed to reciprocal and responsible relationships between multiple sovereign nations with both overlapping and diverging investments (Bears Ears Inter-Tribal Coalition, 2015; Simpson, 2015; Bears Ears InterTribal Coalition, 2016). The BEITC's approach rejects the assumed authority of the federal government to make decisions with only cursory input from Native communities, and instead insists on cooperation between Native nations and the federal government at every step of the process. In this way, the Collaborative Management Plan rejects inclusion in the American public as an organizing force for decision-making, instead insisting on a relational decision-making model rooted in shared commitments to place rather than shared political identity.

As an interdisciplinary field that is deeply invested in the discourses that circulate through the public sphere, rhetoric is uniquely positioned to interrogate settler colonialism's role in the production of publicity. This move is particularly important given the growing contingent of rhetorical scholars calling for attention to the role of settler colonialism in producing rhetorical narratives (for example: Cushman et al., 2019; Na'puti, 2019; McCue-Enser, 2020; Wieskamp and Smith, 2020). Additionally, this is a question that must be addressed as we take up Chávez (2015) call to move "beyond inclusion" in our work. Scholars of environmental participation, in particular, must reckon with settler colonialism's role in determining how deliberation and management processes are structured and whose interests are prioritized in decision-making processes.

\section{DECOLONIZING PUBLICITY IN THE BEITC'S PROPOSAL}

The documents surrounding the creation of the monument highlight the tensions and contradictions inherent in extant environmental decision-making processes, demonstrating a need for new frameworks that can more meaningfully account for the ways in which settler colonialism produces metrics of inclusion and exclusion that preclude Native access to deliberative processes. The BEITC's proposal weaves together separate and sometimes contradictory views of Native people's relationship to the American public in order to call for significant Indigenous oversight of land management practices at Bears Ears. This approach centers Indigenous sovereignty and epistemologies, crafting a rhetoric of decolonization in the context of public participation and public lands management that unsettles extant processes. The Obama and Trump proclamations reproduce the contradictions of settler colonial governance, often failing to meaningfully grapple with the underlying logics that drive the BEITC's proposal. This portion of the essay teases out the rhetorical de/construction of American publics and counterpublics in these documents in order to illustrate the need for new frameworks to address settler colonialism in environmental decision-making contexts.

\section{Inclusions in and Exclusions From "the Public"}

The BEITC's proposal traces the historical and contemporary rhetorics through which Native people have been excluded from constructions of "the public" as a means of denying access to participation in decision-making processes. One coalition member recalls visits to the Bears Ears region when white settlers would tell their family to "go back to the reservation" (Bears Ears Inter-Tribal Coalition, 2015, 12). Another section of the proposal highlights the exclusion of Native people from the decision-making process surrounding the monument, stating "during the 19th Century and much of the 20th, we were kept down, treated by the BIA as if we were children" (Bears Ears Inter-Tribal Coalition, 2015, 14). Through these statements, the proposal highlights the ways that both individual settlers and the settler government have used exclusion from the public to preclude Indigenous participation in decision-making processes. These moves frame Native people as beyond the realm of the public (and therefore not entitled to participation in decision-making processes), either by imposing spatial boundaries that govern belonging (i.e., attempting to confine Native people to reservations understood to be spatially separate from apparently American spaces) or by treating Native people as intellectually inferior and incapable of participating in public discourse.

The proposal further highlights how decision-making bodies have attempted to preclude consideration of Native proposals for the monument. At one point, the proposal states that the BEITC

made its submission to the county, proposing with extensive research and detailed mapping, the creation of a Bears Ears National Conservation Area, to be comanaged by the Tribes. The County never responded. In 2014, the County completed an eighteen-month public land planning process that essentially ignored Native Americans (Bears Ears Inter-Tribal Coalition, 2015, 15).

The proposal, then, becomes a document in which the BEITC can establish this history of exclusion, tracing the ways in which Native people have been excluded from the public sphere and thus access to decision-making processes.

These rhetorical exclusions are reproduced in the presidential proclamations, demonstrating a failure of federal processes to move beyond monolithic understandings of the public. For example, while the Obama proclamation does not explicitly frame the BEITC as either within or outside of the public, it does argue that the national monument designation is not intended solely - or even perhaps primarily - to benefit Native communities. The proclamation states that

Protection of the Bears Ears area will preserve its cultural, prehistoric, and historic legacy and maintain 
its diverse array of natural and scientific resources, ensuring that the prehistoric, historic, and scientific values of this area remain for the benefit of all Americans (U.S. President, 2016, 7).

This statement simultaneously serves to incorporate the BEITC into a monolithic conception of the American public by emphasizing the benefit of the designation for "all Americans," and to remind audiences that the designation is not meant primarily to benefit Native communities. In this move to highlight the universal benefit of establishing a monument, the proclamation erases the Tribes' unique relationships to Bears Ears and minimizes the particular concerns of Native people in favor of justifying the designation as beneficial to non-Native Americans.

Furthermore, the Obama proclamation historicizes Native presence at Bears Ears, functionally relegating Native people to the past and therefore erasing their continued presence and participation in deliberative processes. Throughout the first several pages of the proclamation, Obama states that "native peoples lived in the surrounding deep sandstone canyons, desert mesas, and meadow mountaintops," that "native peoples left traces of their presence," and that many sites at Bears Ears "tell the story of the people who lived here" (U.S. President, 2016, 2-3). These statements center the past presence of Native people in the Bears Ears region, erasing or minimizing the vibrant lives of contemporary Native people. This historicization imposes a temporal boundary that excludes contemporary Native people from participation in deliberation, instead relegating their role in justifying the monument to the past. Native people, from this perspective, become relics of a past that informs, but is not actively a part of, contemporary public good.

Similarly, the Trump proclamation actively severs modern-day Native practices at Bears Ears from arguments about the value of a monument. Trump's proclamation states that "the Antiquities Act requires that any reservation of land as part of a monument be confined to the smallest area compatible with the proper care and management of the objects of historic or scientific interest to be protected" (U.S. President, 2017, 2). By centering "objects of historic or scientific interest," the Trump proclamation argues that modern-day religious and cultural practices cannot serve as justification for the creation of a monument. Like the Obama proclamation, then, the Trump proclamation imposes temporal boundaries designed to de-center Native concerns in the deliberative process. Additionally, in defining the new boundaries of the monument, the Trump proclamation implicitly argues that any areas of significant value to Native people outside of the newly-defined spatial boundaries are not of interest significant enough to warrant federal protection via monument status. In other words, the landscapes, historic dwellings, grave sites, and places where traditions are still practiced that fall outside of the new boundaries may be significant to Native communities, but they are not of import to the American public, for whom the monument exists. Histories of exclusion become justification for Native leadership in the monument-creation process. Continuing the discussion of the 2014 decision from San Juan County, the proposal states
This in spite of the fact that Native people, by 2014 U.S. Census Bureau statistic, comprise almost half of the County's population. Toward the end of the process, the county put up various proposals for public comment but refused to include the Navajo-UDB proposal on the survey. Despite not even being on the survey, the Native American proposal received $64 \%$ of the vote. The wellstated views of the county's Native American citizenry continued to be of no matter to the County (Bears Ears Inter-Tribal Coalition, 2015, 15-16).

Despite being actively excluded, the BEITC argues, Native people still participate vigorously in deliberative processes. The problem here, then, is one of voice. As Senecah (2004) argues, mere presence in decision-making spaces is insufficient to produce real justice if participants are not granted a "trinity of voice." Senecah notes that there are three crucial elements for participation to be meaningful - standing, access, and influence. While the five Tribes might have had access to the voting process, they were denied standing and influence when their proposal was left off the ballot. Nevertheless, Native people living in the county continued to pursue participation in whatever ways were available to them, through participating in the voting process, engaging in negotiations with the county, and - when those options failed to produce results - appealing to the federal government instead. ${ }^{5}$ Thus, the proposal argues for Native communities' place in decision-making processes by demonstrating the determination of Native communities to participate in deliberation even in the face of active marginalization.

This is not to say, however, that the BEITC's proposal pursues more inclusion for Native people in the American public. Throughout the proposal, the BEITC emphasizes that the five Tribes are not merely a subset of a broader American public, but are sovereign nations that cannot and should not be subsumed under settler-centered understandings of American-ness, stating "the Tribes are sovereign governments and possess solid land management capabilities" (Bears Ears Inter-Tribal Coalition, $2015,2)$. The proposal argues that the federal government alone cannot serve Native needs, and that "the effort to preserve Bears Ears has always been premised on Collaborative Management between the Tribes and the federal government. Only then will we Native people have real influence on how this sacred land is managed" (Bears Ears Inter-Tribal Coalition, 2015, 21). Without a serious commitment to Collaborative Management, the BEITC argues that decisionmaking processes will remain a primarily unilateral and topdown process in which the federal government treats Tribes as merely a subset of stakeholders within the American public,

\footnotetext{
${ }^{5}$ I do not mean to argue here that inclusion of the proposal within the County's survey is the same as inclusion of Native communities in the settler public. Instead, I suggest that adding the proposal to the survey would be a means of recognizing and addressing the affects of the Bears Ears decision for Native communities within the decision-making process without subsuming Native people into the broader American public.
} 
rather than as sovereign entities with distinct commitments and investments that cannot be easily wrapped up into conceptions of "public good."

The BEITC offers an alternative to this unilateral and unidirectional process, writing that, "Through an Inter-Tribal coalition, five area tribes are proposing the Bears Ears Monument that would be managed by the tribes and the federal government, where planning, authority, and decision-making are shared equally" (Bears Ears Inter-Tribal Coalition, 2015, 3). They expand on this call for shared decision-making authority in their proposal:

In long, focused, and well-attended deliberations over this proposal, we have concluded that this new monument must be managed under a sensible, entirely workable regime of true Federal-Tribal Collaborative Management. We know that this has never been done before. But most great breakthroughs in public policy have no direct precedent. We want to work with you on this. We have reflected long and hard to come up with the right words to install Collaborative Management in this particular place and circumstance, and believe in our suggested approach, but we welcome your thoughts on how to improve our formulation. Like you, we want to make the Bears Ears National Monument the shining example of the trust, the government-to-government relationship, and innovative, cutting-edge land management. But whatever the specific words might be, for the Bears Ears National Monument to be all it can be, the Tribes must be full partners with the United States in charting the vision for the monument and implementing that vision (Bears Ears Inter-Tribal Coalition, 2015, 3).

Here, the BEITC touts the benefits of Collaborative Management, both as a way to set a precedent for more robust government-to-government relations in the future and as a necessity for caring for Bears Ears. The description of collaborative management as a partnership emerges throughout the proposal and other documents on the BEITC's website, highlighting a commitment to a reciprocal relationship based in mutual care and responsibility that runs counter to the federal government's typical approach of engaging in minimal, unilateral, and unidirectional consultation. In addition to the above quote, the proposal states, "The Tribes, through their deep knowledge of this land, their scientists, their land managers, and their artists and poets and songs, will help present this sacred area to the world in a way that cannot possibly be done without their partnership" (Bears Ears Inter-Tribal Coalition, 2015, 28). Similarly, in their Spring 2020 newsletter, the BEITC writes that,

It is important to recognize how results differ between consultation and involvement with Indigenous peoples-when we listen to the concerns, values, needs, priorities, and ambitions of Indigenous communities there is ample potential to bridge and shape robust working partnerships that are authentic, equitable and inclusive (Bears Ears Inter-Tribal Coalition, 2020).

Through these statements, the BEITC emphasizes partnerships in which Tribes and the US federal government are on equal footing as a necessary component of collaboration, rejecting the idea that Tribes could ever participate as subsidiaries or subordinates of the federal government.

These statements highlight the inability of the federal government - an entity with an apparent commitment to serving the U.S. public - to address Native concerns without collaboration from Native people. While the federal government might be able to address the needs of non-Native American publics, the same cannot be said of Native peoples. Collaboration is essential precisely because inclusion within the American public undermines the sovereignty of Native nations. The solution, then, cannot merely be inclusion within the public, as extant regulatory frameworks would encourage, but rather collaboration between groups who might share goals in the context of the Bears Ears National Monument, but who are not necessarily invested in the same political futures outside of that collaboration.

\section{Re-Imagining Publics Beyond Inclusion}

In the face of these arguments, the BEITC calls for environmental decision-making processes in which Native people can fully participate. These arguments call not for decision-makers to merely listen to Native people as members of the American public, but instead to recognize the multiplicity of relationships to the region held dear both to Native people and to non-Native Americans. In addition to highlighting sovereignty in their discussion of why Native people must be participants in the decision-making process without being subsumed into the public, the proposal emphasizes justifications for the monument which center Native voices. One coalition member, for example, argues that the region must be preserved in order to allow the continued practice of Native traditions. He states,

We go with offerings to our sites. We knock on that wall and say our names - just like you should - you make your entry properly, and address those that reside there as grandmothers and grandfathers as they are. There is no dimension of time in the spirit world. It's good to come here to the sites, to your grandmothers' homes, you remember how it was to be there. With an offering, perhaps some corn meal, you identify yourself, you sing a song and the children dance, and we just speak our language. Your name, your clan, your kiva (Bears Ears Inter-Tribal Coalition, 2015, 9).

This passage highlights a unique relationship between Native people and the Bears Ears region and challenges the idea that public good as a justification for the monument must include or center non-Native people, instead premising the reasoning for the monument on the specific needs of Native people whose histories 
are intimately tied to the area. The primary reason for establishing a monument is made even more explicit when the proposal states, "wondrous though the natural formations are, the most profound aspect of Bears Ears is the Native presence that has blended into every cliff and corner. This spirit is the beating heart of Bears Ears" (Bears Ears Inter-Tribal Coalition, 2015, 8). The desire to protect the monument, from this perspective, has very little to do with non-Native members of the American public. Rather, it is Native histories in particular that must be preserved.

Nevertheless, the proposal does not seek to preclude nonNative access to deliberation about the site in the way that the presidential proclamations marginalize Native concerns. Instead, the proposal recognizes and embraces the multitude of relationships people hold with the Bears Ears region, constructing a deliberative model in which the juxtaposed Native and colonial histories of the site can simultaneously support creating a monument. The proposal carefully navigates the tensions of local settler histories of the region that celebrate pioneering without acknowledging the colonial violence inherent to that settlement by re-telling an origin story held dear by many non-Native descendants of Mormon settlers (Keeler, 2020) ${ }^{6}$. The proposal states, "In 1880, intrepid Mormon pioneers came through this rugged, slickrock country on the historic Hole-in-the-Rock Trail in their horse-drawn wagons and then travelled down to Cedar Mesas to reach Bluff, where they established the first Mormon settlement in the region" (Bears Ears Inter-Tribal Coalition, 2015, 7-8). In framing the monument in this way, the BEITC simultaneously highlights the draw of the monument for non-Native American citizens whose historical connection to the region is founded in pioneering while subtly rejecting versions of that narrative that would posit Mormon pioneers as the first inhabitants of the region by emphasizing that Bluff was "the first Mormon settlement in the region." Rather than relying on a monolithic understanding of "the public" in which all members share common histories or nation-building goals, the BEITC's proposal offers a model for sharing decision-making authority rooted in shared commitments and responsibilities to land instead of shared publicity.

The celebration of pioneering history in this paragraph feels almost out of place in a document otherwise so committed to centering Native perspectives on the site indeed, a document that explicitly notes the harm done by settlers only a few pages later. The passage highlights, however, the ways in which decision-making processes premised on "public good" are fraught with tensions in the context of settler colonialism. Rather than attempting to either to achieve inclusion within "the public" for Native people or invert the hierarchy of participation by including only Native perspectives, the BEITC's proposal embraces this tension and offers a model for decision-making in which shared publicity is not the metric for access. In the BEITC's model, even when groups are invested in incommensurable histories and futurities, they can still

${ }^{6}$ Keeler, J. (2020). personal communication. share decision-making space. Thus, the BEITC's model of shared decision-making authority is rooted in a collaborative approach in which different histories and political commitments are acknowledged and honored, but shared responsibilities to land are at the forefront of the decisionmaking process. Rather than calling for consultation or decision-making based on "public good," the BEITC calls for collaboration across difference.

Rather than becoming a justification for the assimilation of Native people into the American public, this recognition of settler investments in the Bears Ears region becomes a call for settler Americans to take up shared responsibilities for protecting the area. The BEITC calls for an equal partnership in caring for the land rooted not in shared publicity but instead in mutual respect and care across difference. They frame this shared decision-making authority as a means of healing for both people and land. The BEITC suggests that settlers must take responsibility for caring for the land alongside Indigenous people as a way of beginning to heal the harms caused by settler colonialism. In an essay on the relationship between land and culture written for the BEITC's website, Kimmerer (2016) (Potawatomi) writes:

This action [designating Bears Ears National Monument] can aid in healing the land and healing relationship (sic) among peoples by restoring rights of native peoples to jointly care for their homelands. Protecting this cultural landscape also invites settler society; today's citizens of the United States, to recognize that one day, they will also be named among the ancestors of these lands. They have a choice as to what kind of ancestors they wish to be. May we humans live in such a way that the land for whom we are grateful, will be grateful for our presence in return.

Kimmerer's essay calls for a practice of mutual care for the land in which all people - Native and settler - recognize and embrace their responsibilities toward the land and future generations. When paired with shared decision-making authority, this model offers an approach to decision-making that undermines "public good" or "public participation" as the organizing force of decision-making in favor of reciprocity, responsibility, and respect between distinct human communities and land.

\section{Centering Collaboration}

In addition to highlighting the need to move beyond inclusion in the public as the metric for access to participatory spaces, the BEITC also emphasizes the need for collaboration that embraces polyvocality. Rather than attempting to pursue a singular public good that assumes shared investment in the same futurities, the BEITC calls for a process that can simultaneously embrace the exteriority of Native people to the American public and create space for Native participation in decision-making. The BEITC calls for Collaborative Management, which necessitates the involvement of all five Tribes in managing the monument. The proposal states, 
This monument, owned though it is now by the United States, will consist of our ancestral lands. Those lands and our physical legacy in them have been treated badly - horridly, in many instances. The United States has a trust relationship with our sovereign governments. The Tribes, through their deep knowledge of this land, their scientists, their land managers, and their artists and poets, and songs, will help present this sacred area to the world in a way that cannot possibly be done without their partnership (Bears Ears Inter-Tribal Coalition, 2015, 28).

The call for Collaborative Management serves as a way for the BEITC to demand access to decision-making processes. Spaces reserved for the American public too often ignore Native voices. However, processes that emphasize sovereignty may fail to account for the inevitable impacts of public policy and public land management practices on Native people who, though external to the American public in many ways, are still affected by the decisions made by the US government.

While the BEITC celebrates the coalitional relationships between the five Tribes that emerged as a result of working to protect Bears Ears, the proposal is also careful to remind readers that each of the five Tribes are separate entities. Just as the BEITC and non-Native members of the American public may not always be invested in the same futures, the five Tribes may also not always share the same investments. Thus, traditional government-to-government relationships between the federal government and the Tribes would be insufficient to address the plurality of investments in Bears Ears or the complexity of relationships between the five Tribes. Decision-making practices must avoid the trap of bilateral engagement, instead recognizing both the individual sovereignty of each of the five Tribes and the relationships between the five Tribes strengthened through multilateral collaboration over the BEITC proposal. The proposal extrapolates on the need for collaboration, writing:

Federal Indian policy, including the trust relationship, is based on bilateral relationships between recognized sovereign Tribes and the United States. Indian Tribes each have their own individual histories, cultures, and concerns. It is rare that Tribes work together in this fashion, but all the circumstances were right in the case of Bears Ears. "The idea of being a family, all together, one direction, is stronger than individual efforts. The unity of the group fuses all Tribes in the future. Our lifestyle, our food, our way of life seems to be the cornerstone for our position, and I'd like to express my support for that" (Willie Greyeyes, Navajo) (Bears Ears Inter-Tribal Coalition, 2015, 18-19).

This passage demonstrates the difficulty of understanding Native participation in decision-making spaces within the context of the publics/counterpublics framework. While the five Tribes have all been historically denied access to US deliberative processes, they occupy distinct positions that may sometimes align and sometimes diverge. Although Willie Greyeyes argues that cooperation over the monument has resulted in entanglements between the five Tribes that extend beyond the bounds of this struggle, that does not mean that all five Tribes can be flattened into a singular public or counterpublic.

The Trump proclamation, in particular, highlights the failure of federal processes to address the complexities of collaboration between the federal government and multiple Native governments. In addition to shrinking the monument by roughly $85 \%$, the Trump proclamation separated the monument into two sections - the Indian Creek unit and the Shash Jáa unit. Furthermore, the proclamation revised the management plan from the Obama proclamation (which had already reduced the decision-making authority of the commission proposed by the BEITC significantly), stating "the Bears Ears Commission shall be known as the Shash Jáa Commission, shall apply only to the Shash Jáa unit as described herein, and shall also include the elected officer of the San Juan County Commission" (U.S. President, 2017, 8). This change precludes Native oversight of the Indian Creek unit of the monument, which encompasses the Canyonlands Research Center and a number of important rock art sites - including the famous Newspaper Rock, a collection of petroglyphs created by members of numerous Native communities over the course of centuries - and weakens Native agency within the Shash Jáa unit by adding a representative from the San Juan County Commission - the agency responsible for the 2014 exclusions discussed earlier in this essay (U.S. National Park Service, 2018).

Additionally, the modification undermines the careful work of the BEITC to establish a monument that equally values all five Tribes. In a press release published by the BEITC responding to the Trump proclamation, Zuni Councilman Carleton Bowekaty stated, "Even the name, the 'Shash Jáa Tribal Management Council,' is problematic ... By using the Navajo language, they are trying to divide us, but they will not succeed" (Bears Ears Inter-Tribal Coalition, 2018). While the name Bears Ears was chosen by the BEITC in part because it did not privilege one member Tribe over another, the name Shash Jáa centers only Diné relationships to the region, illustrating the failure of federal processes to account for the polyvocality of Native communities.

This flattening of Native nations into a single monolithic counterpublic or subset of the American public demonstrates the difficulty of reconciling publicity as an organizing force for decision-making with Native sovereignty. If decision-making processes assume that all stakeholder groups are merely subsets of a monolithic public with shared investments in settler futurities, then publicity will undermine true multilateral Collaborative Management. Re-orienting decisionmaking processes toward relational practice centers the individual decision-making authority of each Tribal community while simultaneously building structures for collective decision-making regarding land to which multiple communities share commitments. The BEITC writes of this model, "Each Tribe will work to complete their own piece of the plan while also collaborating with each other in this effort to create a wholly new and innovative strategy for protecting cultural landcapes" (Bears Ears Inter-Tribal Coalition, 2020). Thus, decision-making rooted in these kinds of relational 
practices center individual Tribes' sovereignty while also necessitating that each government participating in the decision-making process acknowledge and account for the needs of the others. The constant back-and-forth of individual and collective planning produces a decision-making structure not rooted in the assumption of shared publicity, but instead on shared responsibility across difference.

\section{LESSONS FROM BEARS EARS}

The Bears Ears controversy offers important insights about the public sphere, Native rhetorics, and environmental decisionmaking. The rhetorics deployed in the BEITC's proposal and the presidential proclamations highlight the complexities and contradictions of representation and participation in deliberative democracy in the context of settler colonialism. The BEITC's proposal challenges extant environmental decision-making processes' construction of a monolithic American public by highlighting historical and contemporary settler colonial violence that both functions to exclude Native people from the public and to provide reasons that Native people might not find inclusion within the public desirable. At the same time, however, the proposal does not call for the total exclusion of settlers or the US federal government from Bears Ears. Instead, they offer a model for shared decision-making authority and collaboration that prioritizes Native concerns while also making space for settler commitments to the region. Thus, the Collaborative Management Plan functions as a valuable example of Indigenous futurity, which Tuck and Gaztambide-Fernández $(2013,80)$ argue,

does not foreclose the inhabitation of Indigenous land by non-Indigenous peoples, but does foreclose settler colonialism and settler epistemologies. That is to say that Indigenous futurity does not require the erasure of now-settlers in the ways that settler futurity requires of Indigenous peoples.

The BEITC's model thus rejects settler publicity and settler colonial institutions as the foundation for environmental decision-making, but does not reject the commitments that settler individuals may have to the Bears Ears region or the ability of settlers to participate in shared care for the land.

Whereas much extant literature on publics and counterpublics theorizes counterpublicity as a means of overcoming exclusions, the BEITC instead seeks access to deliberative spaces from a place of exteriority (Fraser, 1990; Asen, 2000). The collaborative management plan offered in the BEITC's proposal thus offers a model for deliberation that is rooted in relational practices of sovereignty. This relational practice may be best aligned with Simpson's (2015, 18) (Michi Saagig Nishnaabeg) definition of sovereignty as "the place where we all live and work together." This conceptualization of sovereignty provides a way of thinking about shared decision-making authority that prioritizes the autonomy and separateness of distinct nations while simultaneously addressing the reality that decisions made by one nation with commitments to a territory necessarily affect other nations with commitments to that territory. From this perspective, the BEITC's collaborative management plan can be understood as a deliberative process in which multiple sovereign nations representing distinct publics with investments in diverging (and often incommensurable) futurities share decision-making authority and deliberative space. Furthermore, this shared decision-making authority functions through a web of shifting relations in which coalitions may form, change, or dissolve based on the needs of each nation in a given moment, where the guiding force in relationships between peoples is shared responsibility to land. In this model, access to participatory processes is predicated not on inclusion within a settler-oriented and singular public - as extant regulatory frameworks posit access - but instead on shared commitments to territory. This understanding of sovereignty may also be useful for understanding how Native nations engage in deliberation not only with the US government but also with one another. Thus, future scholarship of Indigenous and decolonizing rhetorics should take up the task of theorizing sovereignty itself more thoroughly.

Rather than relying on commonplace colonial discourses to highlight the need for a national monument, the BEITC repeatedly highlighted Native people's relationships to the region, emphasized the importance of sovereignty, and linked the need for protecting the site to colonial histories that constrained Native control over and access to the region. While doing all of these things, however, the BEITC also highlighted the historic exclusion of the five Tribes from the American public, emphasized the necessity of maintaining separation via sovereignty, and made arguments about why Native voices must be a part of the decision-making processes. The tensions inherent in this straddling of the boundaries between interiority and exteriority challenge the very framework of public good and public participation that governs access to environmental decision-making processes in the United States (Tuck and Gaztambide-Fernández, 2013). In its place emerges a framework for shared decision-making authority between sovereign nations whose people share commitments to territory without necessitating assimilation into a singular public.

This insistence on centering Indigenous relationships to territory and the history of colonial violation of those relationships presents a radical challenge to settler notions of the public. The BEITC's proposal develops a framework for participation in the designation of public lands that refuses to allow settler colonial narratives about public good to take center stage, but still makes space for settler relationships to land. Rather than calling for expansion of the American public to include Native concerns, the proposal highlights settler colonial exclusion of Native people as an important impetus for Native leadership in the creation and management of the monument. This framing rejects colonial notions of public good that center extractive processes, recreation, and national identity, and instead emphasizes the unique relationships Native people have with the Bears Ears region, the importance of protecting sacred sites and artifacts from looters and polluters, and the necessity of Native leadership both for protecting Bears Ears and strengthening Native self-determination. 
The BEITC challenges the positioning of Native nations in relation to the American public, highlighting how notions of "the public" become complicated when the assumption that all participants in these processes are invested in settler futurities in which the colonial state asserts sovereign authority over colonized territories is rejected (Tuck and Gaztambide-Fernández, 2013). They highlight the colonial nature of participatory processes that are premised on monolithic conceptualizations of the American public rooted in ties to the colonial state. These conceptualizations necessarily create a double-bind in which Indigenous people must either be assimilated as merely a subset of a broader American public or have their concerns ignored as exterior to the interests of "the public." This, in turn, obfuscates Native people's territorial claims. For rhetoricians, this rejection of settler notions of "the public" is valuable, as it opens space for new conceptions of the public that function not only as democratizing forces, but decolonizing forces as well. From this perspective, Indigenous counterpublics pursuing access to decision-making spaces are not necessarily pursuing inclusion within a public sphere that has marginalized them, but rather represent distinct and separate publics calling for the settler public sphere to be altogether dismantled in favor of unimpeded Indigenous sovereignty. Thus, the responses provided by the presidential proclamations fail not only to account for the demands presented in the BEITC's proposal, but fundamentally fail to engage with the grammar of publicity produced in the proposal. The proclamations maintain a commitment to notions of public good that are unable to grapple with the radical change the BEITC calls for. This inability of settler understandings of the public to address decolonizing rhetorics points toward two necessary changes one for environmental decision-making processes, and one for rhetorical scholarship.

First, extant environmental policy's approach to public lands designation and public participation in environmental decisionmaking cannot function as a meaningful tool of decolonization without a radical re-imagining of publicity. Understandings of public good that rely on investments in settler futurities are diametrically opposed to the goals of decolonization (Tuck and Yang, 2012; Tuck and Gaztambide-Fernández, 2013). The logics of cost and benefit that are applied in debates about designating and managing public lands, the frameworks through which stakeholders are positioned in debates about environmental decisions, and the structures of participatory processes serve to protect settler interests in colonized territories over the interests of Native people.

While there has been some attention to settler colonialism in the context of environmental decision-making, there is a need for more intervention that provides approaches to decision-making processes that actively challenge settler colonialism and prioritize Indigenous voices. Many of the problems that other scholars have identified in environmental decision-making processes, such as the de-valuation of marginalized voices as "indecorous" or the "decide-announce-defend" model, among others, may be exacerbated by settler colonial ideologies that prioritize profit, normalize settler occupation, legitimate the settler state, and prioritize (particularly white) settler concerns over those of Indigenous people (Cox, 1999; Hendry, 2004).
Environmental decision-making processes and public lands controversies may be a site where challenges to settler colonialism are uniquely possible. Plans for Collaborative Management and Native-led designation processes may open the door toward wholesale return of land to Native nations. Environmental decision-making processes present this unique opportunity because they are the sites at which competing environmental understandings are negotiated, criteria for future decisions are established, and distributive outcomes are determined. Models like the BEITC's Collaborative Management Plan offer opportunities to chip away at the decision-making authority of the settler state and take steps toward Native nations gaining more control over their territories. These kinds of small shifts in the deliberative landscape might eventually give way to larger pushes for full Indigenous authority over public lands. A particularly optimistic outlook might predict that, given sufficient legal precedent, this expansion of Native governments' authority might be used in the future to argue for the return of land to the Native nations who have been granted management authority. At minimum, implementing models like the BEITC's proposed Collaborative Management Plan are a way of "elbowing out space" for Indigenous nations to exercise decision-making authority in colonized territories (Jacob, 2020).

Second, rhetorical studies must continue to question our investment in the public sphere as a way of framing rhetoric's place in the production of society, and expand that questioning to more thoroughly examine the relationship between the public sphere and settler colonialism. Publicity, as we often approach it, offers a useful way of understanding how individual fragments of discourse exchanged between individuals coalesce into a broader patchwork that contributes to the creation and maintenance of a society. If the goal of that exchange, however, is the improvement and maintenance of the settler state, then thinking through discourse at the level of the public sphere may be unproductive for scholars invested in decolonization. If inclusion within the public necessitates that Native people acquiesce to the violences of settler colonialism, and exclusion from the public means Native voices are silenced or marginalized in conversations about environmental policy, then the framework of publicity becomes a tool of settler colonialism. Thus, we must seek a way of approaching public policy, public good, public participation, and public lands that rejects inclusion in the settler public sphere as the organizing force for access to decision-making processes.

The impetus to demand public participation in environmental decision-making is a useful one. Communities that are affected by decisions must be included in those decisions if environmental justice is to be achieved. At the same time, however, models of environmental decision-making that premise access to those participatory spaces on a monolithic conception of the American Public reproduce the harms of settler colonialism by placing Native people in an impossible double bind; either assimilate to the American public or be left out of decisionmaking spaces. Environmental decision-making spaces already inherently legitimate the settler state by placing final decisionmaking authority in the hands of state and federal agencies. To also commit to a vision of access premised on a monolithic American public is to doubly harm Native people who may not be 
invested in settler futurities. Thus, policies like NEPA that frame environmental decision-making in the context of American identity and settler futurities must be revised or replaced to better account for Native people's investments in decisionmaking processes. While regulations such as these likely cannot be entirely scrapped without inviting additional corporate abuses and environmental degradation, those who head up environmental decision-making processes should reject colonial rhetorics and process designs that prioritize settler concerns or frame decisions in terms of benefits to settler society. This call also has significant implications for the field of rhetorical studies, which relies heavily on concepts like the public sphere and public discourse. We must question how our investments in these terms naturalize settler futurities and develop ways of communicating the importance of rhetoric in the production of the material world that move "beyond inclusion" (Chávez, 2015).

\section{DATA AVAILABILITY STATEMENT}

The original contributions presented in the study are included in the article/supplementary material, further inquiries can be directed to the corresponding author.

\section{REFERENCES}

Asen, R. (2000). Seeking the "Counter," in Counterpublics. Commun. Theor. 10, 424-446. doi:10.1111/j.1468-2885.2000.tb00201.x

J. Barker (2017). Critically Sovereign: Indigenous Gender, Sexuality, and Feminist Studies (Durham, London: Duke University Press).

Bears Ears Inter-Tribal Coalition (2015). Proposal to President Barack Obama for the Creation of Bears Ears National Monument. Available at: http://www. bearsearscoalition.org/wp-content/uploads/2015/10/Bears-Ears-Inter-TribalCoalition-Proposal-10-15-15.pdf

Bears Ears Inter-Tribal Coalition (2016). Bears Ears: A Native Perspective. Available at: https://bearsearscoalition.org/wp-content/uploads/2016/03/Bears-Ears-bro.sm_.pdf. (Accessed August 20, 2020).

Bears Ears Inter-Tribal Coalition (2018). Native American Tribes Oppose H.R. 4532, a Bill to Codify the Repeal and Replacement of Bears Ears National Monument. Bears Ears Inter-tribal Coalition. Available at: https:// bearsearscoalition.org/native-american-tribes-oppose-h-r-4532-a-bill-to-codifythe-repeal-and-replacement-of-bears-ears-national-monument/(Accessed September 9, 2020).

Bears Ears Inter-Tribal Coalition (2020). Spring Newsletter. Bears Ears Inter-Tribal Coalition Newsl. 2, 1-8. (Accessed August 13, 2020)

Bell, S. E. (2013). Our Roots Run Deep as Ironweed: Appalachian Women and the Fight for Environmental justice. Urbana, IL: University of Illinois Press.

S. Benhabib (Editors) (1996). Democracy and Difference: Contesting the Boundaries of the Political (Princeton, NJ: Princeton University Press).

Black, J. E. (2008). Plenary Rhetoric in Indian Country: TheLone Wolf V. HitchcockCase and the Codification of a Weakened Native Character. $A d v$. Hist. Rhetoric 11-12, 59-80. doi:10.1080/15362426.2009.10597380

Branch, E., and Cordalis, D. (2018). The Unlawful Reduction of Bears Ears National Monument: An Executive Overreach. American Bar Association. Available at: https://www.americanbar.org/groups/environment_energy_ resources/publications/trends/2017-2018/may-june-2018/the_unlawful_reduction_ of_bears_ears/. (Accessed April 27, 2020).

Bruyneel, K. (2007). The Third Space of Sovereignty: The Postcolonial Politics of U.S.-Indigenous Relations. Minneapolis, MN: U of Minnesota Press.

\section{AUTHOR CONTRIBUTIONS}

The author confirms being the sole contributor of this work and has approved it for publication.

\section{FUNDING}

Global Change and Sustainability Center - University of Utah: Open access fee.

\section{ACKNOWLEDGMENTS}

The author would like to thank Jacqueline Keeler (Diné/Dakota) for granting me permission to analyze her writings and for taking the time to discuss the Bears Ears case with me. The author would also like to thank the Bears Ears Intertribal Coalition for granting me permission to analyze their proposal and other materials relating to the monument. The author encourage settler scholars to seek prior consent from Indigenous authors before analyzing their published works as a practice of responsibility toward Native people. Additionally, The author would like to thank Danielle Endres for her generous feedback on this essay.

Chávez, K. R. (2015). Beyond Inclusion: Rethinking Rhetoric's Historical Narrative. Q. J. Speech 101, 162-172. doi:10.1080/00335630.2015.994908

Cobb, A. J. (2005). Understanding Tribal Sovereignty: Definitions, Conceptualizations, and Interpretations. Am. Stud. 46, 115-132.

Coffey, W., and Tsosie, R. A. (2001). Rethinking the Tribal Sovereignty Doctrine: Cultural Sovereignty and the Collective Future of Indian Nations. Stanford L. Pol. Rev. 12, 191-221.

Council on Environmental Quality (2007). A Citizen's Guide to NEPA: Having Your Voice Heard. Washington, DC: Council on Environmental Quality, Executive Office of the President.

Cox, J. R. (1999). "Reclaiming the "Indecorous" Voice: Public Participation by Low-Income Communities in Environmental Decision-Making," in Proceedings of the fifth biennial conference on communication and the environment, 21-31.

Cushman, E., Jackson, R., Nichols, A. L., Rivard, C., Moulder, A., Murdock, C., et al. (2019). Decolonizing Projects: Creating Pluriversal Possibilities in Rhetoric Rhetoric Rev. 38, 1-22. doi:10.1080/07350198.2019.1549402

Davidson, L., and Burr, T. (2017). Trump Greeted by Cheers and Protests as $\mathrm{He}$ Visits Utah, Trims 2 Million Acres from Bears Ears and Grand StaircaseEscalante National Monuments - the Salt Lake Tribune. Salt Lake Tribune. Available at: https://www.sltrib.com/news/politics/2017/12/04/trump-is-comingto-utah-to-perform-dramatic-feat-monday-make-big-national-monuments-mostlydisappear/(Accessed April 27, 2020).

Deloria, V., and Wilkins, D. E. (1999). Tribes, Treaties, \& Constitutional Tribulations. Austin, TX: University of Texas Press.

Deloria, V. (1988). Custer Died for Your Sins. Norman, OK: University of Oklahoma Press.

EagleWoman, A. T. (2012). Bringing Balance to Mid-North America: Restructuring the Sovereign Relationships between Tribal Nations and the United States. North Am. 41, 671-707.

Echohawk, J. E. (2017). President Trump's Bears Ears Order Is an Illegal Attack on Tribal Sovereignty. Huffpost. Available at: https://www.huffpost.com/entry/trump-bearsears-tribal-sovereignty_b_5a25b663e4b03c44072fcc02. (Accessed April 27, 2020).

Endres, D. (2009). The Rhetoric of Nuclear Colonialism: Rhetorical Exclusion of American Indian Arguments in the Yucca Mountain Nuclear Waste Siting Decision. Commun. Critical/Cultural Stud. 6, 39-60. doi:10.1080/14791420802632103 
Endres, D. (2012). Sacred Land or National Sacrifice Zone: The Role of Values in the Yucca Mountain Participation Process. Environ. Commun. 6, 328-345. doi:10.1080/17524032.2012.688060

Endres, D. (2013). Animist Intersubjectivity as Argumentation: Western Shoshone and Southern Paiute Arguments against a Nuclear Waste Site at Yucca Mountain. Argumentation 27, 183-200. doi:10.1007/s10503-012-9271-x

Estes, N. (2019). Our History Is the Future: Standing Rock versus the Dakota Access Pipeline and the Long Tradition of Indigenous Resistance. New York, NY: Verso.

Evans, J. H. (2020). Can the Public Express Their Views or Say No through Public Engagement? Environ. Commun. 14, 881-885. doi:10.1080/ 17524032.2020.1811459

Fairbanks, R. A. (1995). Native American Sovereignty and Treaty Rights: Are They Historical Illusions? Am. Indian L. Rev. 20, 141. doi:10.2307/20068787

Fraser, N. (1990). Rethinking the Public Sphere: A Contribution to the Critique of Actually Existing Democracy. Social Text 25/26, 56-80. doi:10.2307/ 466240

Friedland, L. A., Hove, T., and Rojas, H. (2006). The Networked Public Sphere. Javnost - The Public. 13, 5-26. doi:10.1080/13183222.2006.11008922

Habermas, J. (1989). The Structural Transformation of the Public Sphere: An Inquiry into a Category of Bourgeois Society. Cambridge, UK: Polity Press.

Hannum, H. (1998). Sovereignty and its Relevance to Native Americans in the Twenty-First Century. Am. Indian L. Rev. 23, 487-495. doi:10.2307/ 20068898

Hauser, G. A., and Benson, T. W. (1999). Vernacular Voices: The Rhetoric of Publics and Public Spheres. Columbia, SC: Univ of South Carolina Press.

Hendry, J. (2004). "Decide, Announce, Defend: Turning the NEPA Process into an Advocacy Tool rather than a Decision-Making Tool," in Communication And Public Participation in Environmental Decision Making. Editors S. Depoe, J. W. Delicath, and M.-F. A. Elsenbeer (Albany, NY: SUNY Press)), 99-112.

Hoover, E. (2017). The River Is in Us: Fighting Toxics in a Mohawk Community. Minneapolis, MN: University of Minnesota Press. doi:10.5749/j.cttlpwt6mk

Ishiyama, N. (2003). Environmental Justice and American Indian Tribal Sovereignty: Case Study of a Land-Use Conflict in Skull Valley, Utah. Antipode 35, 119-139. doi:10.1111/1467-8330.00305

Jacob, M. M. (2020). Indigenous Education Is for Everyone.

Johnson, T. N. (2019). The Dakota Access Pipeline and the Breakdown of Participatory Processes in Environmental Decision-Making. Environ. Commun. 13, 335-352. doi:10.1080/17524032.2019.1569544

Keeler, J. (2017). "Introduction," in In Edge Of Morning: Native Voices Speak For the Bears Ears. Editor J. Keeler (Salt Lake City, UT: Torrey House Press), 1-6.

Kimmerer, R. W. (2016). Traditional Knowledge and Bears Ears. Bears Ears Intertribal Coalition. Available at: https://bearsearscoalition.org/traditionalknowledge-and-bears-ears/. (Accessed February 16, 2021).

Kinsella, W. J. (2004). "Public Expertise: A Foundation for Citizen Participation in Energy and Environmental Decisions," in Communication And Public Participation in Environmental Decision Making. Editors S. P. Depoe, J. W. Delicath, and M.-F. A. Elsenbeer (Albany, NY: SUNY Press), 83-98.

LaDuke, W. (2008). Climate Change, Peak Oil and Food Security: Challenges and Strategies for This Millennium. The Ninth Annual Student Scholarship and Creative Achievement Conference, Bemidji, MN (Bemidji State University).

Lake, R. A. (1983). Enacting Red Power: The Consummatory Function in Native American Protest Rhetoric. Q. J. Speech 69, 127-142. doi:10.1080/ 00335638309383642

Lipton, E., and Friedman, L. (2018). Oil Was Central in Decision to Shrink Bears Ears Monument, Emails Show. The New York Times. Available at: https://www. nytimes.com/2018/03/02/climate/bears-ears-national-monument.html. (Accessed February 12, 2021).

McCue-Enser, M. (2020). Genocide in the Sculpture Garden and Talking Back to Settler Colonialism. Q. J. Speech 106, 179-204. doi:10.1080/00335630.2020.1744181

Morgensen, S. L. (2011). Spaces between Us: Queer Settler Colonialism and Indigenous Decolonization. Minneapolis, MN: $\mathrm{U}$ of Minnesota Press. doi:10.5749/minnesota/9780816656325.001.0001

Na'puti, T. R. (2019). Speaking of Indigeneity: Navigating Genealogies against Erasure and \#RhetoricSoWhite. Q. J. Speech 105, 495-501. doi:10.1080/ 00335630.2019 .1669895
National Environmental Policy Act (1969). National Environmental Policy Act. Available at: https://www.energy.gov/sites/default/files/nepapub/nepa documents/RedDont/Req-NEPA.pdf (Accessed July 19, 2020)

National Historic Preservation Act (1966). National Historic Preservation Act. Available at: https://www.nps.gov/history/local-law/nhpa1966.htm (Accessed July 19, 2020).

Office of Outdoor Recreation Office of Outdoor Recreation Utah Governor's Office Of Economic Development. Available at: https://business.utah.gov/outdoor/. (Accessed September 3, 2020).

Pezzullo, P. C. (2003). Resisting "National Breast Cancer Awareness Month": the Rhetoric of Counterpublics and Their Cultural Performances. Q. J. Speech 89, 345-365. doi:10.1080/0033563032000160981

Pfister, D. (2014). Networked media, Networked Rhetorics: Attention and Deliberation in the Early Blogosphere. Pennsylvania: University ParkThe Pennsylvania State University Press. doi:10.5325/j.ctv8j4cn

L. Phillips, A. Carvalho, and J. Doyle (Editors) (2012). Citizen Voices: Performing Public Communication in Science and Environment Communication (Bristol, UK: Intellect).

Sanchez, J., Stuckey, M. E., and Morris, R. (1999). Rhetorical Exclusion: The Government's Case against American Indian Activists, AIM, and Leonard Peltier. Am. Indian Cult. Res. J. 23, 27-52. doi:10.17953/ aicr.23.2.j579763666w5381k

Senecah, S. (2004). "The trinity of Voice: The Role of Practical Theory in Planning and Evaluating the Effectiveness of Environmental Participatory Processes," in Communication And Public Participation in Environmental Decision Making. Editors S. P. Depoe, J. W. Delicath, and M.-F. A. Elsenbeer (Albany, NY: SUNY Press), 13-34.

Shome, R. (1996). Postcolonial Interventions in the Rhetorical Canon: An "Other" View. Commun. Theor. 6, 40-59. doi:10.1111/j.14682885.1996.tb00119.x

Simpson, A. (2014). Mohawk Interruptus: Political Life across the Borders of Settler States. Durham, NC: Duke University Press. doi:10.2307/ j.ctv1198w8z

Simpson, L. B. (2015). "The Place where We All Live and Work Together: A Gendered Analysis of 'sovereignty," in Native Studies Keywords. Editors S. N. Teves, A. Smith, and M. H. Raheja (Tuscon, AZ: University of Arizona Press), 18-24.

Smith, J. (2020). The Moving Boundaries of Bears Ears: Ecological Rhetorics and the Shrinking of a Monument. Rhetoric Soc. Q. 50, 352-367. doi:10.1080/ 02773945.2020 .1813323

Spivak, G. C. (1988). "Can the Subaltern Speak?," in In Marxism And the Interpretation of Culture. Editors C. Nelson and L. Grossberg (Urbana, IL: University of Illinois Press), 271-313. doi:10.1007/978-1-34919059-1_20

Sprain, L., and Reinig, L. (2018). Citizens Speaking as Experts: Expertise Discourse in Deliberative Forums. Environ. Commun. 12, 357-369. doi:10.1080/ 17524032.2017.1394894

Stephenson, M. (2002). Forging an Indigenous counterpublic sphere: The taller de historia oral andina in Bolivia. Latin Am. Res. Rev. 37, 99-118.

Tuck, E., and Gaztambide-Fernández, R. A. (2013). Curriculum, Replacement, and Settler Futurity. Journal of Curriculum Theorizing 29. , 2013 Available at: https://journal.jctonline.org/index.php/jct/article/view/411. (Accessed June 14, 2020).

Tuck, E., and Yang, K. W. (2012). Decolonization Is Not a Metaphor. Decolonization: Indigeneity, Educ. Soc. 1, 1-40.

U.S. National Park Service (2018). Newspaper Rock - Petrified Forest National Park. National Park Service. Available at: https://www.nps.gov/pefo/learn/ historyculture/newspaper-rock.htm. (Accessed April 27, 2020).

U.S. President (2016). Proclamation, "Establishment of the Bears Ears National Monument, Proclamation 9558 of December 28, 2016. Fed. Reigist. 32, 1139-1147. Available at: https://www.federalregister.gov/documents/2017/01/ 05/2017-00038/establishment-of-the-bears-ears-national-monument (Accessed July 19, 2021).

U.S. President (2017). Proclamation, "Modifying the Bears Ears National Monument, Proclamation 9681 of December 4, 2017. Fed. Regist. 32, 5808158087. Available at: https://www.federalregister.gov/documents/2017/ 12/08/2017-26709/modifying-the-bears-ears-national-monument (Accessed July 19, 2021). 
Johnson

Indigenous Publicity and Public Lands

Vizenor, G. (2008). Survivance: Narratives of Native Presence. Lincoln, NE: U of Nebraska Press.

Walker, G. B., Daniels, S. E., and Emborg, J. (2015). "Public Participation in Environmental Policy Decision Making: Insights from Twenty Years of Collaborative Learning Fieldwork," in The Routledge Handbook of Environment and Communication. Editors A. Hansen and R. Cox (New York, NY: Routledge)), 111-130.

Wieskamp, V. N., and Smith, C. (2020). "What to Do when You're Raped": Indigenous Women Critiquing and Coping through a Rhetoric of Survivance. Q. J. Speech 106, 72-94. doi:10.1080/00335630.2019.1706189

Witkin, A. (1995). To Silence a Drum: The Imposition of United States Citizenship on Native Peoples. Hist. Reflect. Réflexions Historiques 21, 353-383.

Witt, D. E., and Hartley, B. (2020). Recognizing Multiple Sovereignties: A Starting point for Native American Cultural Resource Consultation. J. Community Archaeol. Herit. 7, 3-16. doi:10.1080/20518196.2019.1654673

Wolfe, P. (2001). Land, Labor, and Difference: Elementary Structures of Race. Am. Hist. Rev. 106, 866-905. doi:10.2307/2692330

Wolfe, P. (2006). Settler Colonialism and the Elimination of the Native. J. genocide Res. 8, 387-409. doi:10.1080/14623520601056240

Wolfley, J. (1991). Jim Crow, Indian Style: The Disenfranchisement of Native Americans. Am. Indian L. Rev. 16, 167-202. doi:10.2307/20068694

Youdelis, M. (2016). "They Could Take You Out for Coffee and Call it Consultation!": The Colonial Antipolitics of Indigenous Consultation in
Jasper National Park. Environ. Plan. A. 48, 1374-1392. doi:10.1177/ 0308518X16640530

Young, I. M. (1996). "Communication and the Other: Beyond Deliberative Democracy," in In Democracy And Difference: Contesting the Boundaries of the Political. Editor S. Benhabib (Princeton, NJ: Princeton University Press), 120-135.

Conflict of Interest: The author declares that the research was conducted in the absence of any commercial or financial relationships that could be construed as a potential conflict of interest.

Publisher's Note: All claims expressed in this article are solely those of the authors and do not necessarily represent those of their affiliated organizations, or those of the publisher, the editors and the reviewers. Any product that may be evaluated in this article, or claim that may be made by its manufacturer, is not guaranteed or endorsed by the publisher.

Copyright (c) 2021 Johnson. This is an open-access article distributed under the terms of the Creative Commons Attribution License (CC BY). The use, distribution or reproduction in other forums is permitted, provided the original authors) and the copyright owners) are credited and that the original publication in this journal is cited, in accordance with accepted academic practice. No use, distribution or reproduction is permitted which does not comply with these terms.

Frontiers in Communication | www.frontiersin.org

16

July 2021 | Volume 6 | Article 673115 